\title{
Organic Matter Accumulation Mechanism in the Lower Cambrian Strata from Well Luntan 1 in the Tarim Basin, NW China
}

\author{
Qian Deng, ${ }^{1,2,3}$ Haizu Zhang, ${ }^{4}$ Haozhe Wang, ${ }^{1,2,3}$ Zhiwei Wei, ${ }^{1,2,3}$ Bin Cheng $\left(\mathbb{D},{ }^{1,2}\right.$ \\ Shida Li, ${ }^{1,2,3}$ Yunpeng Wang, ${ }^{1,2}$ Oluwabamise Lekan Faboya, ${ }^{1,2}$ and Zewen Liao ${ }^{1,2}$ \\ ${ }^{1}$ State Key Laboratory of Organic Geochemistry, Guangzhou Institute of Geochemistry, Chinese Academy of Sciences, \\ Guangzhou 510640, China \\ ${ }^{2}$ CAS Center for Excellence in Deep Earth Science, Guangzhou 510640, China \\ ${ }^{3}$ University of Chinese Academy of Sciences, Beijing 100049, China \\ ${ }^{4}$ Research Institute of Petroleum Exploration and Development, PetroChina Tarim Oilfield Company, Korla 841000, China
}

Correspondence should be addressed to Bin Cheng; chengbin@gig.ac.cn

Received 22 October 2020; Revised 4 January 2021; Accepted 25 January 2021; Published 8 February 2021

Academic Editor: Micòl Mastrocicco

Copyright (c) 2021 Qian Deng et al. This is an open access article distributed under the Creative Commons Attribution License, which permits unrestricted use, distribution, and reproduction in any medium, provided the original work is properly cited.

\begin{abstract}
A large amount of light crude oils have been found within 4000 to $7000 \mathrm{~m}$ deep strata of Cambrian, Ordovician, and Silurian reservoirs in the Tarim Basin, NW China. To enhance the understanding of parental materials of deep oils, a set of high-quality source rocks from the Yuertusi Formation in well Luntan 1 (maximum drilling depth of $8882 \mathrm{~m}$ ) was studied in terms of their sedimentary condition and mechanism of organic matter enrichment. Total organic carbon (TOC) content, carbon isotope of kerogen $\left(\delta^{13} \mathrm{C}_{\mathrm{ker}}\right)$, and major and trace elements of the rocks from the Sinian Qigebulake, Cambrian Yuertusi, and Xiaoerbulake Formations in well Luntan 1 were analysed. The results showed that the $\delta^{13} \mathrm{C}_{\mathrm{ker}}$ value of the Yuertusi Formation barely changed with an average of $-31.19 \%$. High TOC contents accompanied by enrichments of the bioessential trace elements, such as cadmium, chromium, copper, nickel, and zinc, occurred in the lower part of the Yuertusi Formation. Excess barium $\left(\mathrm{Ba}_{\mathrm{xs}}\right)$ and phosphorus concentrations revealed high primary productivity during the deposition of the Yuertusi Formation. Moreover, variations in the enrichment factors of molybdenum, uranium, and vanadium and molybdenum-uranium covariation pattern indicated suboxic-anoxic conditions in the Qigebulake Formation, anoxic-euxinic conditions in the Yuertusi Formation, and suboxic-oxic conditions in the Xiaoerbulake Formation. The TOC contents were significantly correlated with the paleoproductivity and paleoredox parameters, indicating that high productivity and reducing conditions jointly controlled the organic matter accumulation and preservation in well Luntan 1.
\end{abstract}

\section{Introduction}

In many hydrocarbon-producing basins in China, exploration activities have recently been geared towards the deep and ultradeep areas, leading to the ancient strata receiving significant attention. The Cambrian and even the Proterozoic in the deeper part of the basins are increasingly becoming the hot spots for research and exploration activities [1-5]. Analyses of the oil-gas geology of deep wells over $7000 \mathrm{~m}$ depth have shown that the low limit of depth range for the generation of deep hydrocarbons is wide and the source rocks at high maturity stage still have good hydrocarbon generation potential [6]. The deep and ultradeep reservoirs from
Chinese Marine Craton basins, therefore, may contain a large pool of oil and gas resources [3-8].

The Cambrian oil reservoirs, such as the wells of TS1, ZS1, ZS1C, and TD2, have been constantly discovered in the Tarim Basin [9-13]. In January 2020, light crude oil was discovered from the Lower Cambrian dolomite with a burial depth greater than $8200 \mathrm{~m}$ in well Luntan 1, which penetrated a set of high-quality source rocks in the Cambrian Yuertusi Formation and two sets of reservoir-cap assemblages. These include the evaporite gypsum cap rocks in the Awatage Formation and dolomite reservoir in the ShayilikeWusonggeer Formations and mudstone cap in the Yuertusi Formation and dolomite weathering crust reservoir in the 


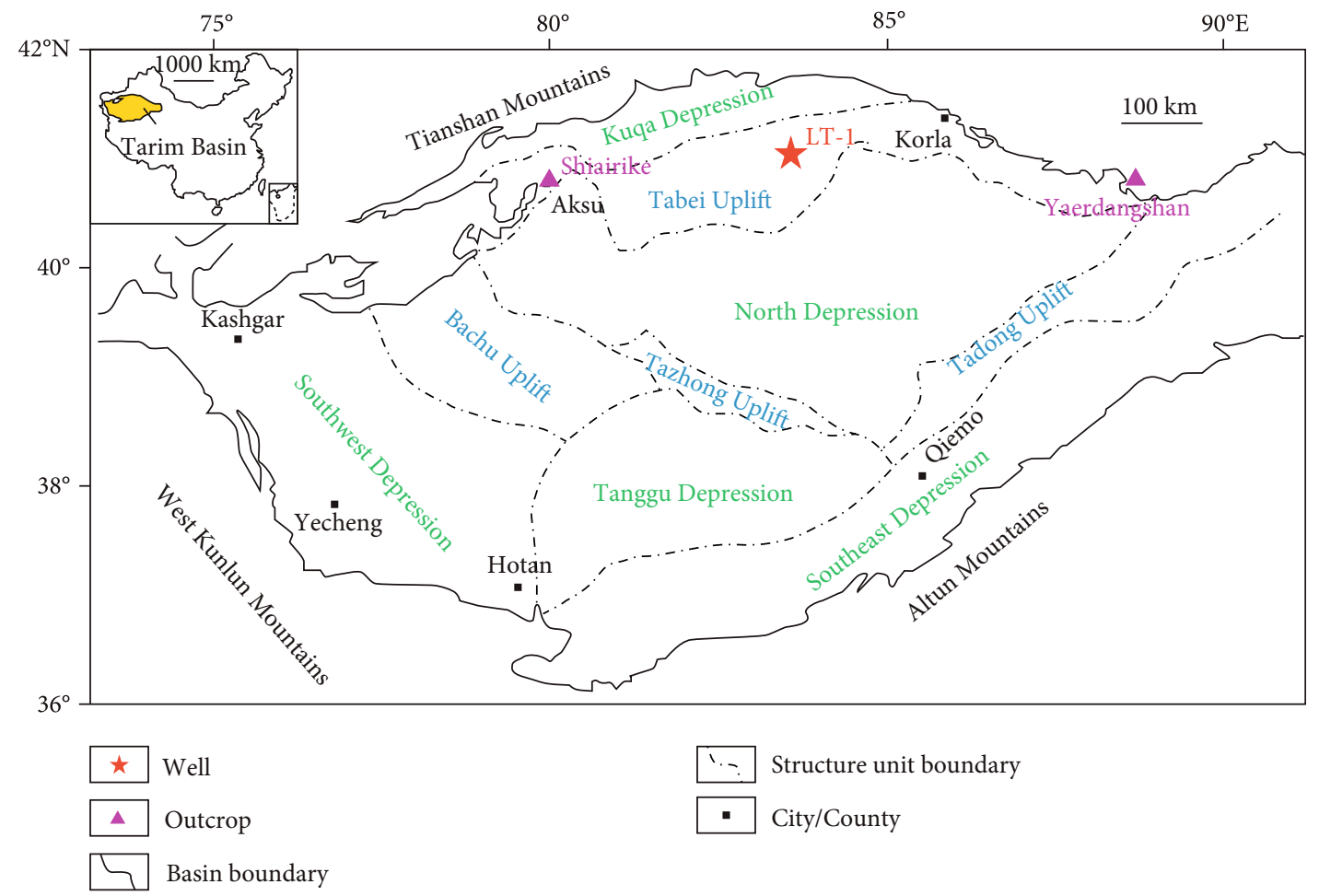

Figure 1: Tectonic unit distribution in the Tarim Basin $[29,30]$ and the location of well Luntan 1 (LT-1) [14].

Sinian Qigebulake Formation. The drilling of well Luntan 1 is a breakthrough in ultradeep oil and gas exploration in the old craton of the Tarim Basin [14]. Those oil reservoirs found further reveal that the Cambrian strata of the Tarim Basin have a vast exploration field and exploration potential.

Those crude oil resources are believed to originate from the source rocks of the Cambrian Yuertusi Formation based on many oil-source correlation analyses [10, 15-18]. The Yuertusi Formation contains high-quality source rocks [19] for which the study on organic matter accumulation mechanism is still lacking. Prior studies proposed that several factors control the organic matter enrichment, including paleoredox, paleoproductivity, paleoclimate, upwelling, hydrothermal fluids, terrigenous detritus input, basin restriction, and combinations of them [20-26]. Deng et al. recently suggested that the organism assemblage type, terrigenous detritus input, and sedimentation rate might have brought about the different TOC content preserved in the Yuertusi Formation from the Shiairike section and the Xishanbulake Formation (time equivalent to the Yuertusi Formation) from the Yaerdangshan section in the Tarim Basin [27]. However, the most important factors controlling the organic matter accumulation in a particular research area should be studied specifically, because the main controls on organic matter accumulation may vary in different sedimentary settings $[26,28]$. It will be significant to study the depositional environment of the Yuertusi Formation source rocks from well Luntan 1 and factors controlling their organic matter development for the prediction of oil/gas distribution and new hydrocarbon exploration activities.

The present study was conducted to investigate the distribution of TOC content, carbon isotope composition of kero- gen $\left(\delta^{13} \mathrm{C}_{\mathrm{ker}}\right)$, and major and trace elements of the rocks from Sinian-Lower Cambrian of well Luntan 1 in the Tarim Basin. This is expected to provide useful information on the sedimentary conditions, organic matter enrichment, and preservation mechanisms of the Lower Cambrian Yuertusi source rocks.

\section{Geological Setting}

The Tarim Basin is located in the Uygur Autonomous Region of Xinjiang, northwest China, and covers an area of $560,000 \mathrm{~km}^{2}$. It is shaped like a giant eyeball, bounded by the orogenic belts of the Tianshan Mountains in the north, the west Kunlun Mountains in the southwest, and the Altun Mountains in the southeast (Figure 1). The basin is partitioned into five depressions (Kuqa, North, Southwest, Southeast, and Tanggu) and four uplifts (Tabei, Bachu, Tazhong, and Tadong) $[29,30]$.

Well Luntan 1 is located at the Lunnan low bulge in the Tabei Uplift, with a maximum drilling depth of $8882 \mathrm{~m}$ at the Sinian Sugaitebulake Formation. The Tabei Uplift is located in the northern part of the Tarim Basin, with a length of $480 \mathrm{~km}$ from east to west and a width of $70-110 \mathrm{~km}$ from north to south. It is a pre-Jurassic paleouplift that strikes near east-west and spreads slightly northward. The Lunnan low bulge sits on the center of the Tabei Uplift and is bounded by the Luntai fault with Luntai uplift in the north. In the south is the Northern Depression, in the west is the Yingmaili low bulge, and in the east is the Caohu Depression. With a total area of about $14,000 \mathrm{~km}^{2}$, the Lunnan low bulge is the main area of the Lunnan-Tahe-Halahatang Oil field $[31,32]$. 


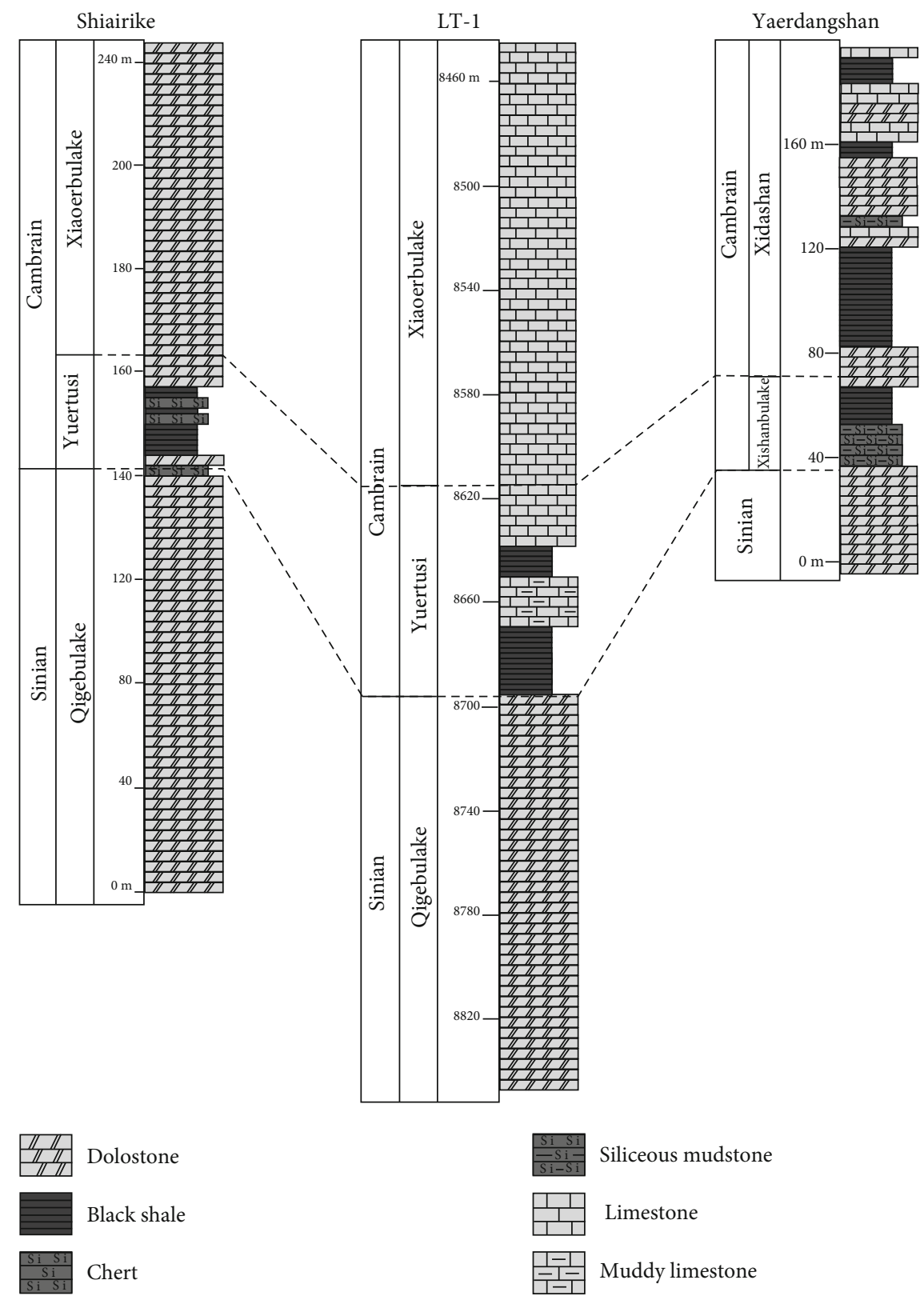

FIgURE 2: Stratigraphic correlations of Sinian-Lower Cambrian between well Luntan 1 [14], the Shiairike [19], and Yaerdangshan sections [34].

Sedimentary successions in the Lunnan low bulge are well developed. They ranged from bottom to top in the following order: Sinian, Cambrian, Ordovician, Silurian, Devonian, Carboniferous, Permian, Triassic, Jurassic, Cretaceous, Paleogene, Neogene, and Quaternary. Among them, the strata from the Sinian to Ordovician, the Silurian to Permian, and the Meso-Cenozoic are marine carbonate, paralic, and continental deposits, respectively $[31,32]$. The Lunnan low bulge is characterised by "multiple oil-gas accumulation play" with Cambrian, Ordovician, Carboniferous, and Triassic as the main hydrocarbon-bearing strata [33].

In this work, the Sinian Qigebulake Formation (8696$8847 \mathrm{~m}$ ), the Lower Cambrian Yuertusi Formation (8615$8696 \mathrm{~m})$, and the Xiaoerbulake Formation (8444-8615 m) from well Luntan 1 are the focus strata. The Qigebulake Formation consists of dolostones. The Yuertusi Formation rests unconformably upon the Qigebulake Formation and underlies the Xiaoerbulake Formation. It is comprised of black shales in the lower part and muddy limestones and limestones in the upper part [14]. The thickness of the Yuertusi Formation in well Luntan 1 is $81 \mathrm{~m}$, much thicker than that in the Shiairike section in the northwestern Tarim Basin (Figure 2). The Xiaoerbulake Formation is dominated by limestones, which is distinct from the time-equivalent Xidashan Formation from the Yaerdanghshan section in the northeastern Tarim Basin (Figure 2). This indicates a spatial heterogeneous depositional environment in the northern and northeastern Tarim Basin during the early Cambrian. 


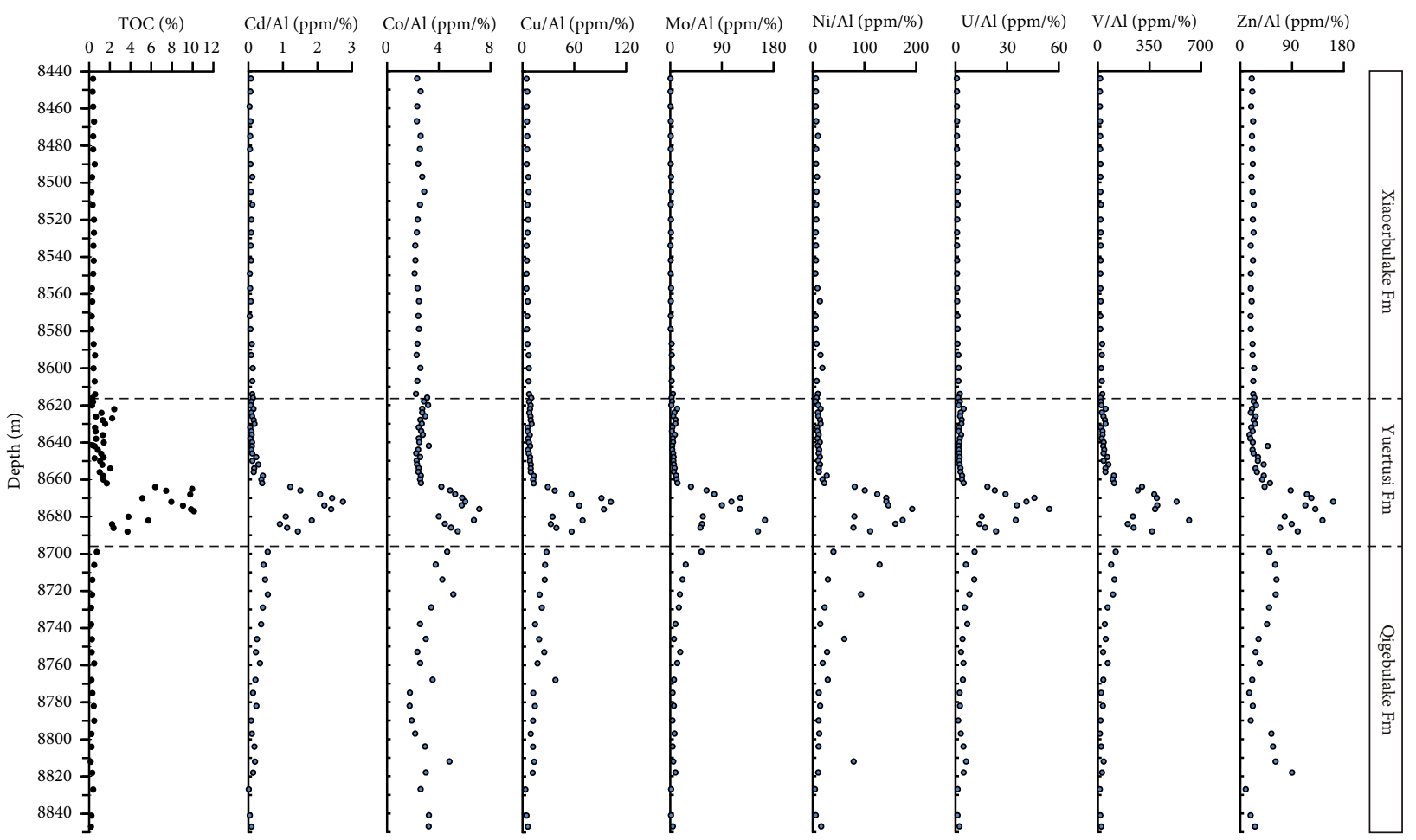

Figure 3: Profiles of TOC, $\mathrm{Cd} / \mathrm{Al}, \mathrm{Co} / \mathrm{Al}, \mathrm{Cu} / \mathrm{Al}, \mathrm{Mo} / \mathrm{Al}, \mathrm{Ni} / \mathrm{Al}, \mathrm{U} / \mathrm{Al}, \mathrm{V} / \mathrm{Al}$, and $\mathrm{Zn} / \mathrm{Al}$ in well Luntan 1.

\section{Materials and Methods}

After careful screening of drill cutting samples from well Luntan 1, 85 samples including 20 from the Qigebulake Formation, 41 from the Yuertusi Formation, and 24 from the Xiaoerbulake Formation were selected. Rock samples with large angular sizes and no obvious contamination were crushed into 200 mesh. Analyses of the TOC content, carbon isotope of kerogen, and major and trace elements were performed.

For TOC analysis, $80-120 \mathrm{mg}$ powdered sample was treated with a $15 \% \mathrm{HCl}$ solution for over $24 \mathrm{~h}$ for complete carbonate removal. The decalcified solid residue was washed repeatedly with deionised water until the $\mathrm{pH}$ value of the solution approached 7 . The solid residue was then dried at $60^{\circ} \mathrm{C}$ before analysis. TOC analysis was conducted with an Eltra CS-800 Carbon Sulfur Determinator.

Six source rocks from the Yuertusi Formation were selected to the kerogen enrichment. Each powdered sample $(\sim 50 \mathrm{~g})$ was treated repeatedly with dilute $\mathrm{HCl}$ and $\mathrm{HF}$ for the removal of carbonate and silicate minerals. The residual kerogens were washed with deionised water until a neutral state was attained and then dried. The $\delta^{13} \mathrm{C}_{\mathrm{ker}}$ values were measured using an elemental analyser coupled with a conflow interface that automatically transfers carbon dioxide gas into a Finnigan Delta Plus mass spectrometer. The standard deviation of the carbon isotopic values was less than $\pm 0.3 \%$ o.

For major element analysis, the samples were mixed thoroughly with lithium nitrate and melted at a high temperature. Major element contents were then measured by a
Philips PW2404 X-ray fluorescence spectrometer. The relative deviation was smaller than $5 \%$, and the relative error of the elemental concentration was smaller than $2 \%$. For trace element analysis, the powdered rock samples were digested with $\mathrm{HNO}_{3}-\mathrm{HClO}_{4}-\mathrm{HF}-\mathrm{HCl}$ mixed acids, and organic-rich samples were combusted at $750^{\circ} \mathrm{C}$ to sufficiently remove organic matter before digestion. Trace element concentrations were determined by an Agilent 7700x inductively coupled plasma mass spectrometer (ICP-MS) combined with an Agilent VISTA inductively coupled plasma atomic emission spectrometer (ICP-AES). The relative deviation and the relative error of elemental concentration were less than $10 \%$.

\section{Results and Discussion}

4.1. TOC and $\delta^{13} C_{k e r}$. The TOC values of the rocks from the Qigebulake, Yuertusi, and Xiaoerbulake Formations ranged from 0.15 to $0.73 \%$ (avg. $0.33 \%$ ), 0.27 to $10.13 \%$ (avg. $3.0 \%$ ), and 0.22 to $0.58 \%$ (avg. $0.40 \%$ ), respectively (Table S1). The highest TOC content occurs in the lower part of the Yuertusi Formation (Figure 3).

The $\delta^{13} \mathrm{C}_{\mathrm{ker}}$ values of the six kerogens from the Yuertusi Formation in well Luntan 1 varied from $-31.50 \%$ to $-30.01 \%$ (Table S1), with an average value of $-31.19 \%$. The $\delta^{13} \mathrm{C}_{\mathrm{ker}}$ values displayed no significant variation.

Carbon source utilization and photosynthesis are the major factors influencing carbon isotopic fractionation of organic matter synthesis by organism; thus, the different organism assemblages could lead to variations in $\delta^{13} \mathrm{C}_{\mathrm{ker}}$. For example, the $\delta^{13} \mathrm{C}_{\mathrm{ker}}$ values of the Lower Paleozoic 


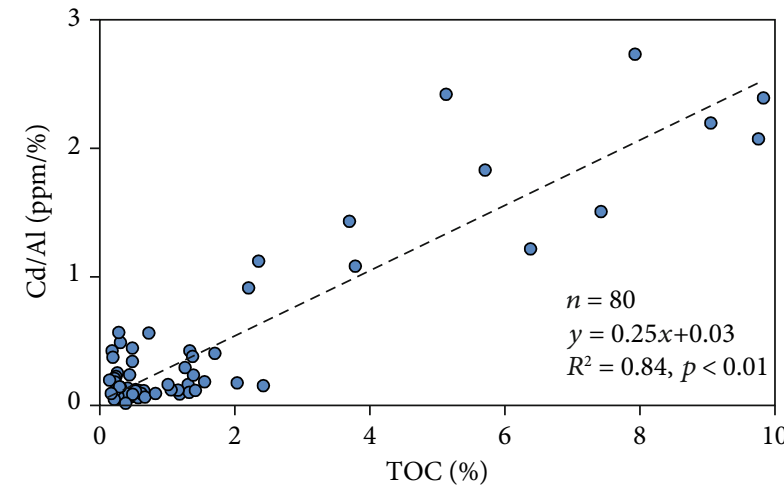

(a)

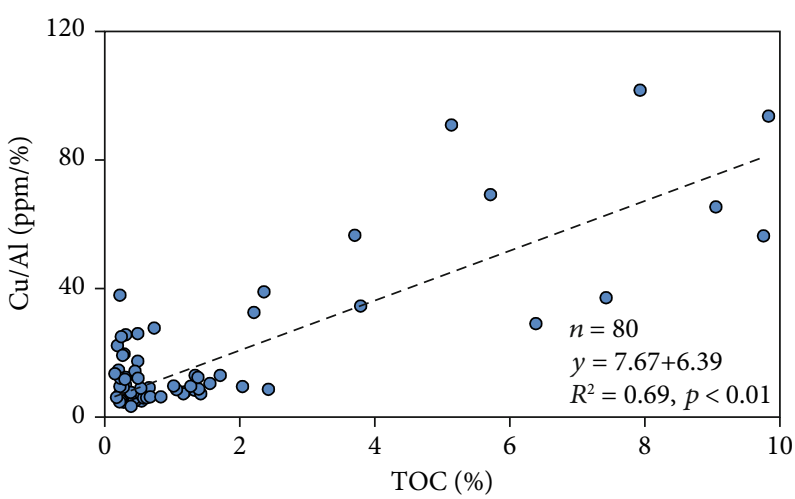

(c)

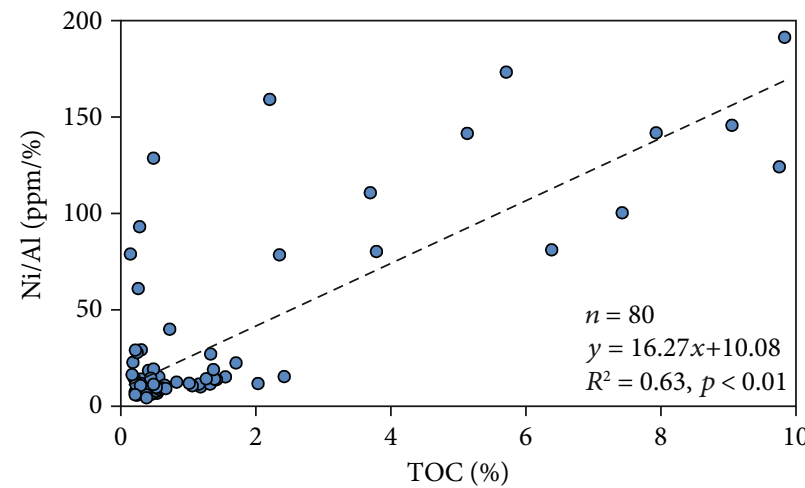

(e)

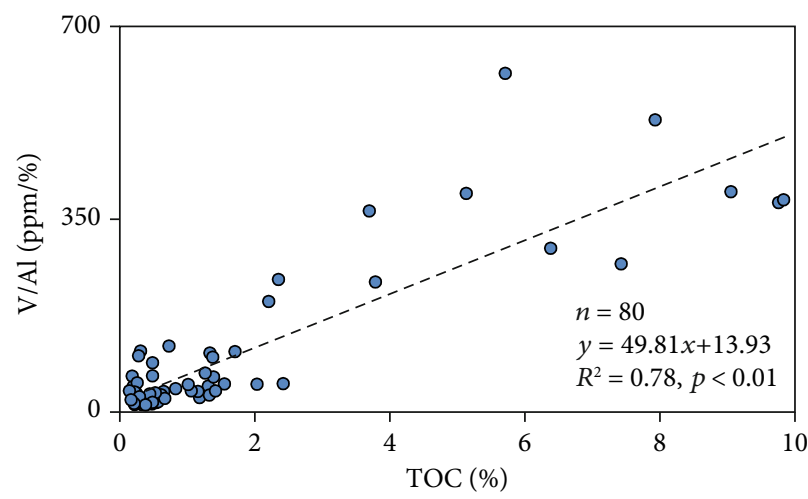

(g)

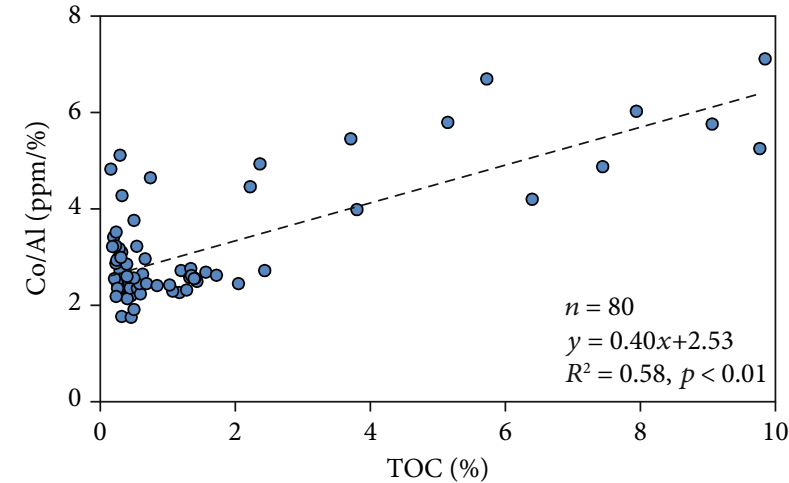

(b)

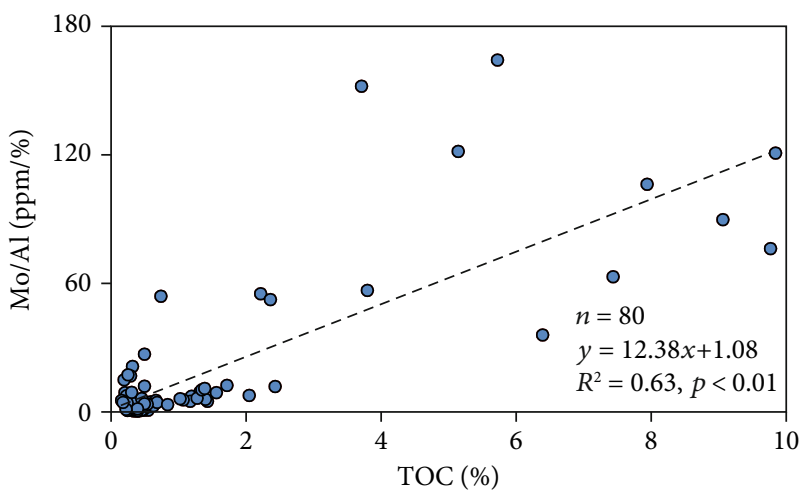

(d)

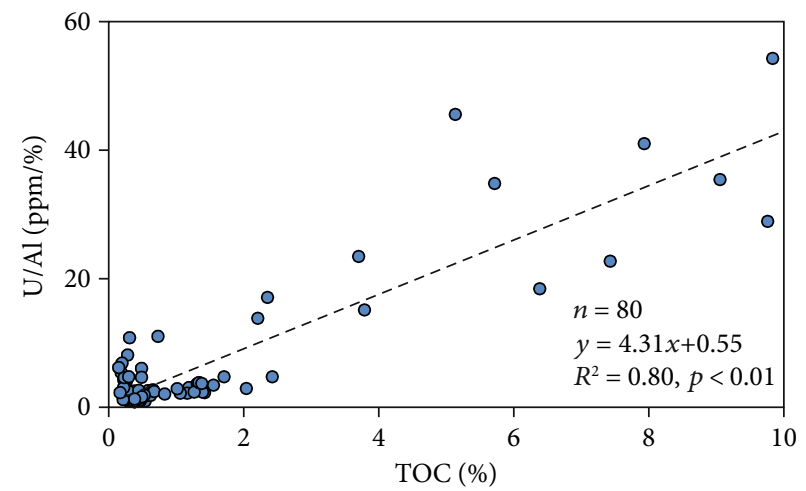

(f)

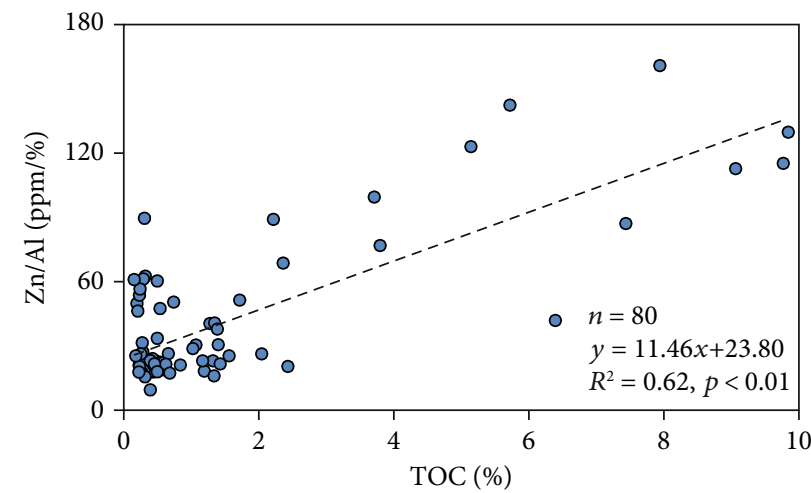

(h)

Figure 4: Crossplots of (a) Cd/Al, (b) $\mathrm{Co} / \mathrm{Al}$, (c) $\mathrm{Cu} / \mathrm{Al}$, (d) Mo/Al, (e) Ni/Al, (f) U/Al, (g) V/Al, and (h) Zn/Al versus TOC. 


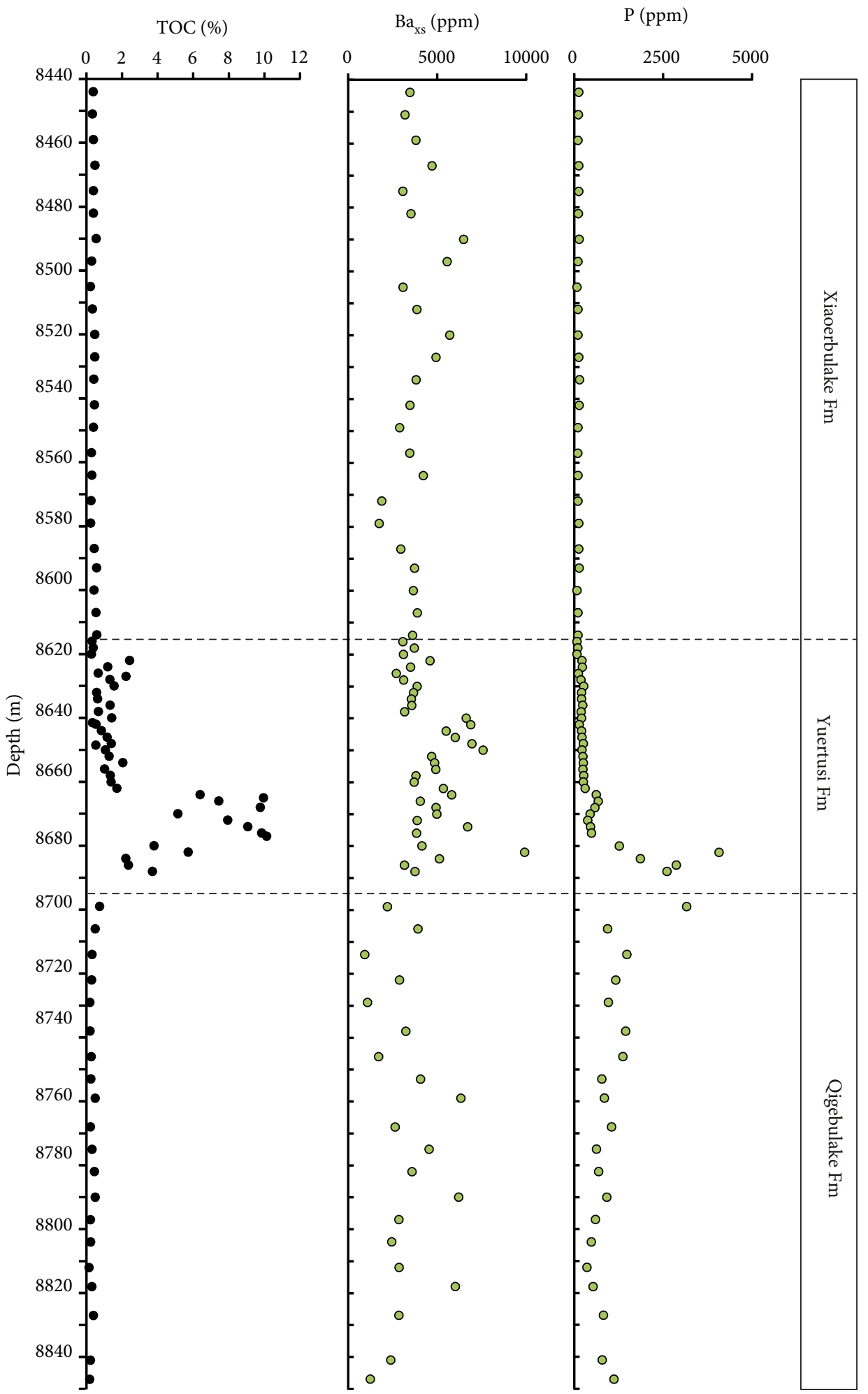

Figure 5: Profiles of TOC, $\mathrm{Ba}_{\mathrm{xs}}$, and $\mathrm{P}$ content in well Luntan 1.

potential source rocks dominated by benthic algae are lower than $-34 \%$, whereas the $\delta^{13} \mathrm{C}_{\mathrm{ker}}$ values of the source rocks dominated by planktonic algae are higher than $-30 \%$ in the Tarim Basin [35, 36]. Previous research on the outcrop source rocks from the Lower Cambrian Xishanbulake Formation in the eastern Tarim Basin and the Lower Cambrian
Yuertusi-Xiaoerbulake Formation in the western Tarim Basin indicated that the bioprecursors assemblage changed from benthic algae to planktonic algae [37]. In contrast to that, the $\delta^{13} \mathrm{C}_{\mathrm{ker}}$ values in the Yuertusi Formation from well Luntan 1 did not show any significant vertical variation, indicating that the marine environment and organism 


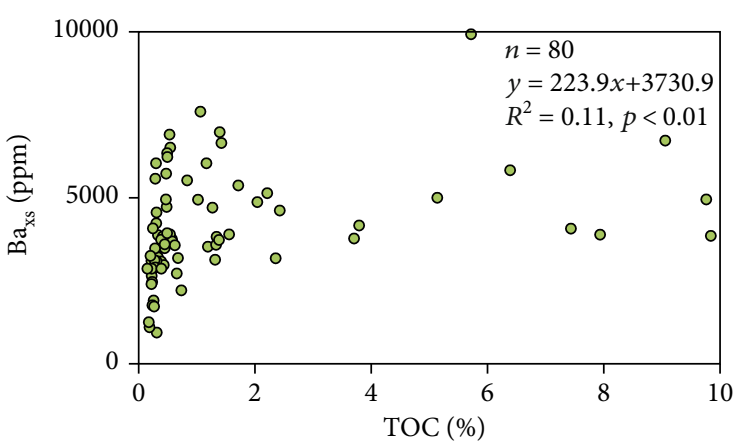

(a)

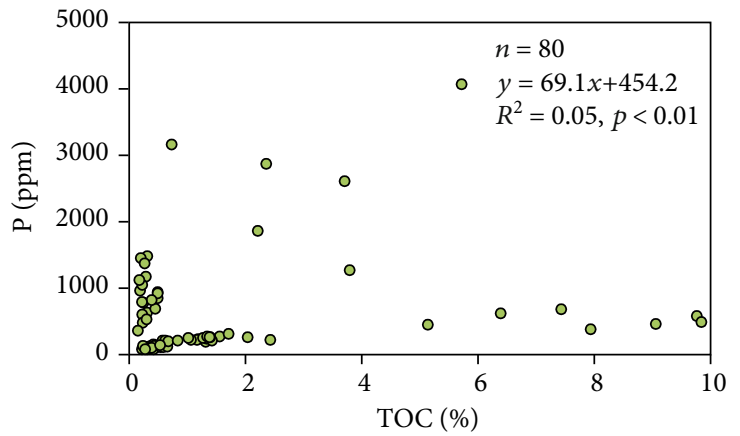

(b)

Figure 6: Crossplots of (a) $\mathrm{Ba}_{\mathrm{xs}}$ and (b) $\mathrm{P}$ content versus TOC.

assemblages did not change during the deposition of the Yuertusi Formation in well Luntan 1.

4.2. Trace Element Distribution. Trace element barium (Ba), cadmium $(\mathrm{Cd})$, cobalt $(\mathrm{Co})$, copper $(\mathrm{Cu})$, molybdenum (Mo), nickel (Ni), uranium (U), vanadium (V), and zinc $(\mathrm{Zn})$ and major element aluminum (Al) and titanium (Ti) contents in rocks from well Luntan 1 are presented in Table S2. The trace element abundances of the samples from the three formations exhibited an order of $\mathrm{Ba}>$ $\mathrm{P}>\mathrm{V}>\mathrm{Zn}>\mathrm{Ni}>\mathrm{Mo}, \mathrm{Cu}, \mathrm{U}, \mathrm{Co}$, and $\mathrm{Cd}$. In the present study, the trace element/Al ratio was used to correct for dilution of authigenic minerals [38]. The results showed that these trace elements were most concentrated in the lower part of the Yuertusi Formation, which was synchronous with the high TOC contents (Table S3, Figure 3). Besides, $\mathrm{Cd} / \mathrm{Al}$, $\mathrm{Co} / \mathrm{Al}, \mathrm{Cu} / \mathrm{Al}, \mathrm{Mo} / \mathrm{Al}, \mathrm{Ni} / \mathrm{Al}, \mathrm{U} / \mathrm{Al}, \mathrm{V} / \mathrm{Al}$, and $\mathrm{Zn} / \mathrm{Al}$ were positively related to the TOC contents (Figure 4).

$\mathrm{Cd}, \mathrm{Co}, \mathrm{Cu}, \mathrm{Ni}$, and $\mathrm{Zn}$ are known bioessential as structural components and reactive centers in proteins or metalloenzymes, playing key roles in various enzymatic reactions, including photosynthesis, nitrogen fixation, and other synthesis or catabolism processes $[39,40]$. The coupling of high TOC content and high concentration of bioessential trace elements in the lower part of the Yuertusi Formation suggested that these trace elements promoted the development of organisms as micronutrients and were eventually incorporated into the sediments along with the organic matter. The increased productivity provided strong material support for the accumulation of organic matter.

4.3. Paleoproductivity Assessment. Biogenic $\mathrm{Ba}$ and $\mathrm{P}$ are typical proxies for appraising productivity in ancient sediments as they often show a good correlation with marine primary productivity [41-44]. Biogenic $\mathrm{Ba}$ is represented by the nondetrital fraction or the part in excess of the average shale abundance (excess fraction) of $\mathrm{Ba}$ that is calculated as follows $[44,45]$ :

$$
\mathrm{Ba}_{\mathrm{xs}}=\mathrm{Ba}_{\text {total }}-\mathrm{Ti} \times(\mathrm{Ba} / \mathrm{Ti})_{\text {PAAS }}
$$

where $\mathrm{Ba}_{\mathrm{xs}}, \mathrm{Ba}_{\text {total }}, \mathrm{Ti}$, and $(\mathrm{Ba} / \mathrm{Ti})_{\text {PAAs }}$ represent the excess element $\mathrm{Ba}$, the total concentration of $\mathrm{Ba}, \mathrm{Ti}$ concentration, and the concentration ratio of $\mathrm{Ba}$ to $\mathrm{Ti}$ in post-Archean
Australia average shale (PAAS), respectively. The PAAS data were taken from [46].

$\mathrm{Ba}_{\mathrm{xs}}$ and $\mathrm{P}$ contents were utilised in the evaluation of the paleoproductivity of the Sinian-Lower Cambrian strata from well Luntan 1 (Figure 5). The interval with the highest productivity was located in the Yuertusi Formation, with $\mathrm{Ba}_{\mathrm{xs}}$ values ranged from 2712.33 to $9919.83 \mathrm{ppm}$ (avg. $4701.16 \mathrm{ppm}$ ). The $\mathrm{Ba}_{\mathrm{xs}}$ values obtained for the Qigebulake and Xiaoerbulake Formations ranged from 935.92 to $6335.33 \mathrm{ppm}$ (avg. $3207.94 \mathrm{ppm}$ ) and 1755 to $6502 \mathrm{ppm}$ (avg. $3790.79 \mathrm{ppm}$ ), respectively (Table $\mathrm{S} 3$ ). While the $\mathrm{Ba}_{\mathrm{xs}}$ values in the Lower Cambrian organic-rich beds in Yangtze Block mostly range from 700 to $1300 \mathrm{ppm}$, similar to values in modern high productivity marine settings [47].

The lower part of the Yuertusi Formation was greatly enriched in phosphorus with the $\mathrm{P}$ content ranging from 1270 to $4070 \mathrm{ppm}$. It was believed that a large number of phosphorus was transported by upwelling currents when a large-scale transgression event occurred during the early Cambrian in the Tarim Basin [48-50]. The phosphorus enrichment indicated high productivity during the period of Yuertusi Formation deposition. The weak correlation between $\mathrm{Ba}_{\mathrm{xs}}$ and TOC, as well as $\mathrm{P}$ content and TOC (Figure 6), implied an effect of the local environment on $\mathrm{Ba}$ and $\mathrm{P}$ in seawater, such as remobilization and recycling [43]. Other paleoproductivity indicators, such as $\mathrm{Cu}, \mathrm{Ni}$, and $\mathrm{Zn}$, are less influenced by redox conditions $[41,51]$. The significant positive correlations between the element ratios $(\mathrm{Cu} / \mathrm{Al}, \mathrm{Ni} / \mathrm{Al}$, and $\mathrm{Zn} / \mathrm{Al})$ and $\mathrm{TOC}$ content (Figure 4) also indicated an important role of productivity in the accumulation of organic matter. Overall, the beds with high TOC content generally had high productivity.

4.4. Paleoredox Condition Analysis. Fe speciation, pyrite framboid size, $\mathrm{C}_{\text {org }} / \mathrm{P}$, and the elemental ratios of $\mathrm{Th} / \mathrm{U}$, $\mathrm{V} / \mathrm{Cr}, \mathrm{V} / \mathrm{Sc}, \mathrm{Ni} / \mathrm{Co}$, and $\mathrm{V} /(\mathrm{V}+\mathrm{Ni})$ have been applied for paleoredox analysis [52-57], but some recent studies suggested that the redox threshold values should not be directly applied in different paleodepositional systems [58, 59]. Redox-sensitive trace elements, such as Mo, U, and V, are generally enriched in sedimentary rocks under reducing conditions, allowing them as important proxies for evaluating paleoredox conditions [41]. They are believed more consistently useful than other redox proxies on evaluating 


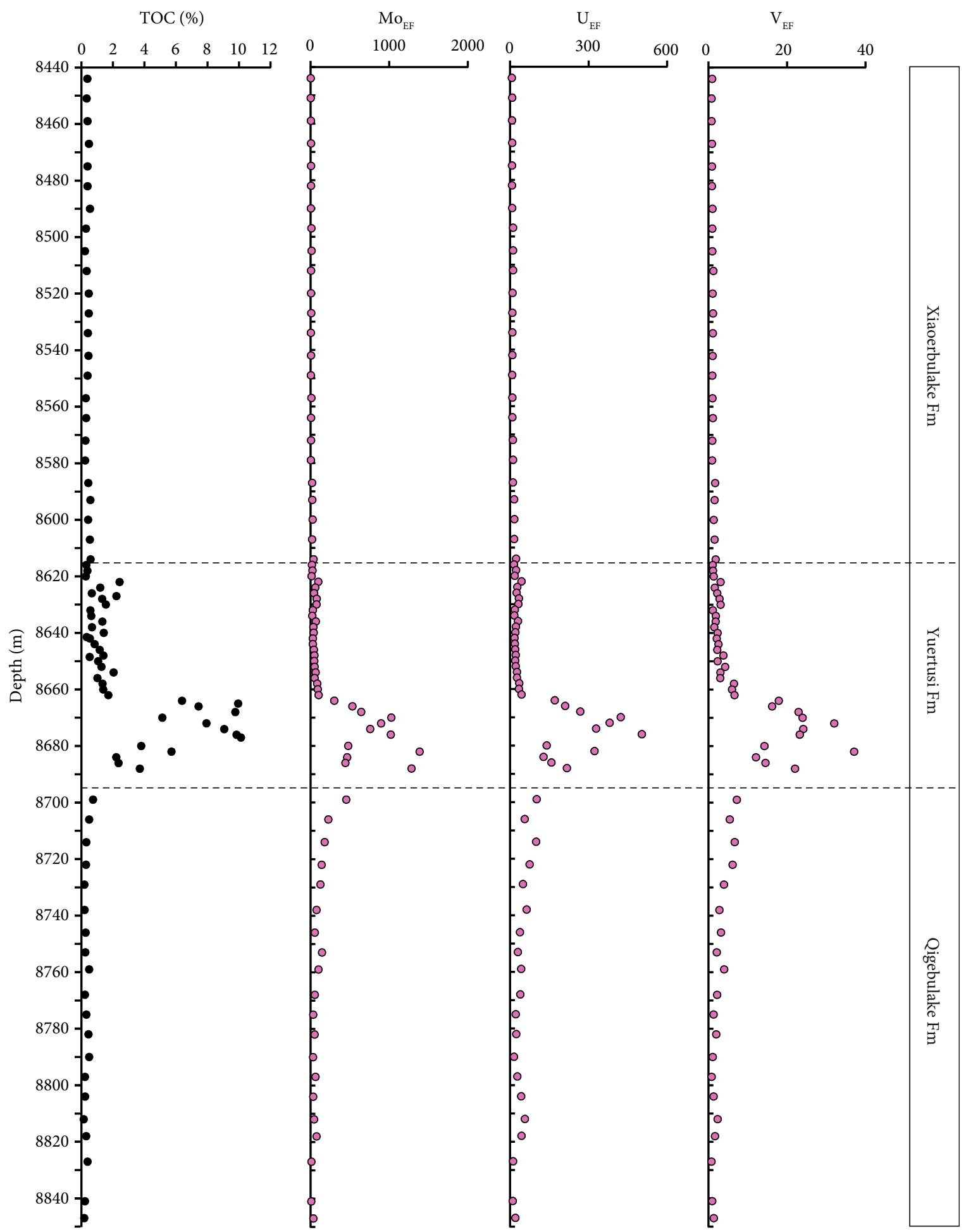

Figure 7: Profiles of TOC, $\mathrm{Mo}_{\mathrm{EF}}, \mathrm{U}_{\mathrm{EF}}$, and $\mathrm{V}_{\mathrm{EF}}$ in the Sinian-Lower Cambrian in well Luntan 1.

paleoredox conditions [59]. Here, Mo, U, and V were utilized in the present study to illustrate the evolution of marine redox conditions during the Sinian-early Cambrian.

The enrichment factor $(\mathrm{EF})$ of trace element relative to PAAS is generally calculated as follows:

$$
\mathrm{X}_{\mathrm{EF}}=(\mathrm{X} / \mathrm{Al})_{\text {sample }} /(\mathrm{X} / \mathrm{Al})_{\mathrm{PAAS}},
$$

where $\mathrm{X}_{\mathrm{EF}},(\mathrm{X} / \mathrm{Al})_{\text {sample }}$, and $(\mathrm{X} / \mathrm{Al})_{\mathrm{PAAS}}$ represent the enrichment factor of element $\mathrm{X}$, the ratio of element $\mathrm{X}$ to $\mathrm{Al}$ in the sample, and the ratio of element $\mathrm{X}$ to $\mathrm{Al}$ in PAAS, respectively. The $\mathrm{Mo}_{\mathrm{EF}}, \mathrm{U}_{\mathrm{EF}}$, and $\mathrm{V}_{\mathrm{EF}}$ of the rocks from the Qigebulake Formation ranged from 10.20 to $455.67,11.08$ to 102.30 , and 0.79 to 7.23 , respectively (Table S3, Figure 7), showing minor to moderate enrichment of Mo, $\mathrm{U}$, and $\mathrm{V}$ and 


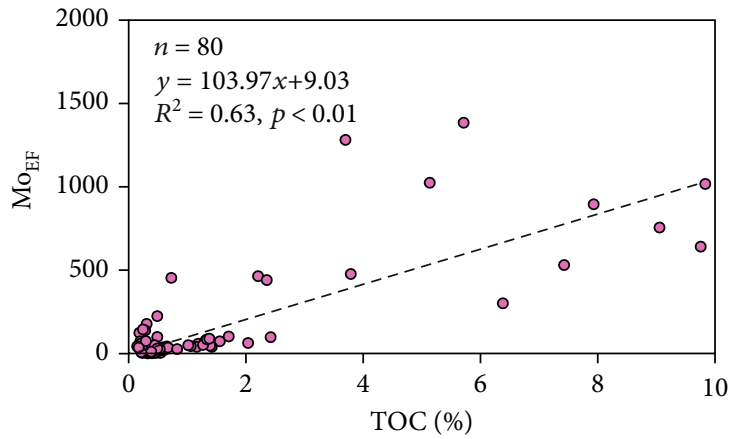

(a)

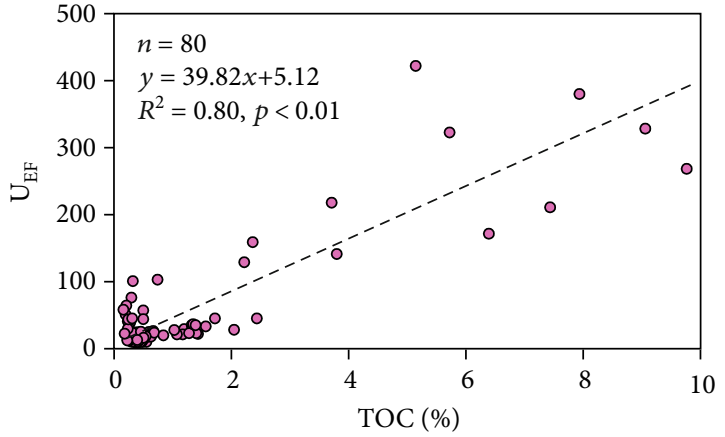

(b)

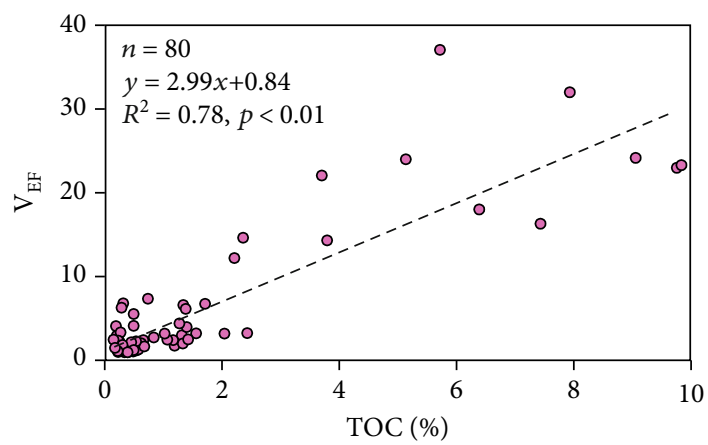

(c)

Figure 8: Crossplots of (a) $\mathrm{Mo}_{\mathrm{EF}}$, (b) $\mathrm{U}_{\mathrm{EF}}$, and (c) $\mathrm{V}_{\mathrm{EF}}$ versus TOC.

suboxic-anoxic conditions. The three trace elements in the Yuertusi Formation were extremely enriched, especially in the lower part of the formation, with $\mathrm{Mo}_{\mathrm{EF}}$ of 19.411386.72, $\mathrm{U}_{\mathrm{EF}}$ of 15.38-503.74, and $\mathrm{V}_{\mathrm{EF}}$ of 1.07-37.09. These indicated that the Yuertusi Formation was deposited in anoxic-euxinic environments. The Xiaoerbulake Formation barely enriched Mo, $\mathrm{U}$, and $\mathrm{V}$ with $\mathrm{Mo}_{\mathrm{EF}}$ of 3.41-39.85, $\mathrm{U}_{\mathrm{EF}}$ of 7.64-23.85, and $\mathrm{V}_{\mathrm{EF}}$ of $0.81-1.82$, indicating suboxic-oxic depositional environments. $\mathrm{Mo}_{\mathrm{EF}}, \mathrm{U}_{\mathrm{EF}}$, and $\mathrm{V}_{\mathrm{EF}}$ presented good correlations with TOC content (Figures 7 and 8). It showed that the TOC contents were higher in sediments deposited in graver reducing conditions, signifying that the preservation of organic matter in well Luntan 1 was primarily controlled by reducing conditions. Overall, the general trend observed from the different proxies used in this study indicated increasing anoxia from the Qigebulake Formation to the lower part of the Yuertusi Formation and an increasing oxidation tendency from the lower part of the Yuertusi Formation to the Xiaoerbulake Formation. It was also evident from the $\mathrm{Mo}_{\mathrm{EF}}-\mathrm{U}_{\mathrm{EF}}$ covariation pattern (Figure 9(a)), which was proved useful in the analysis of paleoceanographic environments [60].

Mo-TOC covariation pattern in modern anoxic marine environments is applicable to anoxic paleomarine systems for hydrographic analysis $[61,62]$. In Figure 9(b), there is a positive correlation between Mo concentration and TOC content, again indicative of the oxygen-depleted depositional environments of the Yuertusi Formation [41]. Some $\mathrm{Mo} / \mathrm{TOC}$ values were similar to that of Saanich Inlet and Cariaco Basin [60], reflecting a mild to moderate water mass restriction over a certain period. Additionally, the Mo-TOC covariation pattern from the Yuertusi Formation of the outcrop sections also indicates a semirestricted shallow water environment [63]. The similarity between the trace element concentrations of the Yuertusi Formation in the Tarim Basin and the Cariaco Basin sediments had previously been reported [50]. It is believed that the passive continental margin of the Tarim Basin is affected by the upwelling of oceanic hydrothermal fluids.

4.5. Organic Matter Accumulation Mechanism of the Yuertusi Formation from Well Luntan 1 in the Tarim Basin. Several development models of the Lower Cambrian source rocks in the Tarim Basin have been established in prior studies. For instance, the thermal fluid activity, upwelling currents, and anoxic event model [64], the gentle slope model [29], the middle-lower gentle slope and shelf model [19], and the shallow water overlapping sedimentary model [62] have been proposed. A consensus has been reached that the sedimentary of the Yuertusi Formation was influenced by sea-level changes, hydrothermal activities, upwelling, and organic matter preservation conditions [19, 26, 63, 64].

During the Sinian-Cambrian transition, extensional tectonic movements along with large-scale volcanic and hydrothermal activities occurred in the Tarim Basin [50, 65-67]. With a transgression event in the earliest Cambrian [26], upwelling of hydrothermal fluids that hosted abundant nutrient elements such as $\mathrm{Ba}, \mathrm{P}, \mathrm{Cd}, \mathrm{Cu}, \mathrm{Ni}, \mathrm{V}$, and $\mathrm{Zn}$ (Figure 10) promoted the development of organisms on the continental shelf. The original organism assemblages of the Yuertusi Formation including planktonic and benthic 


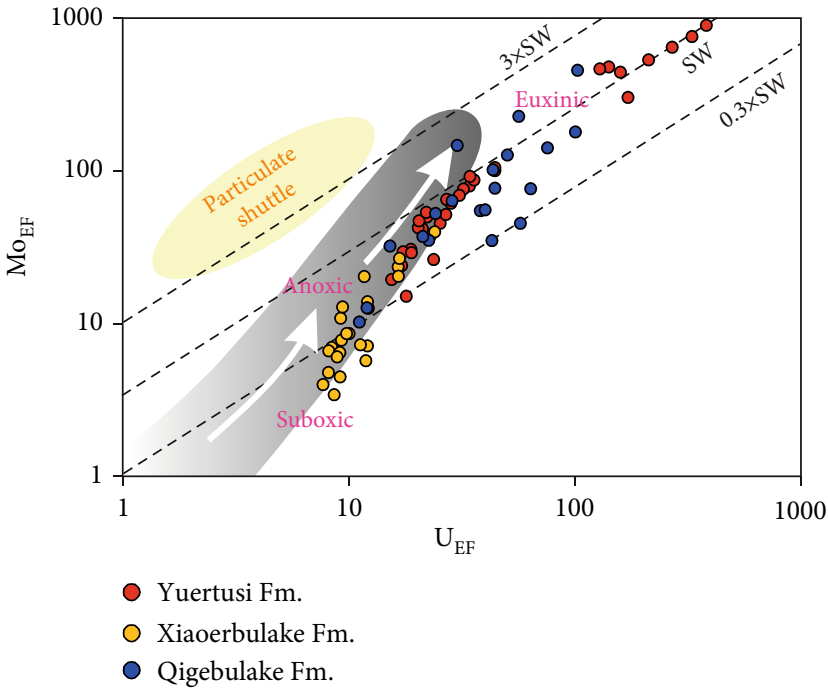

(a)

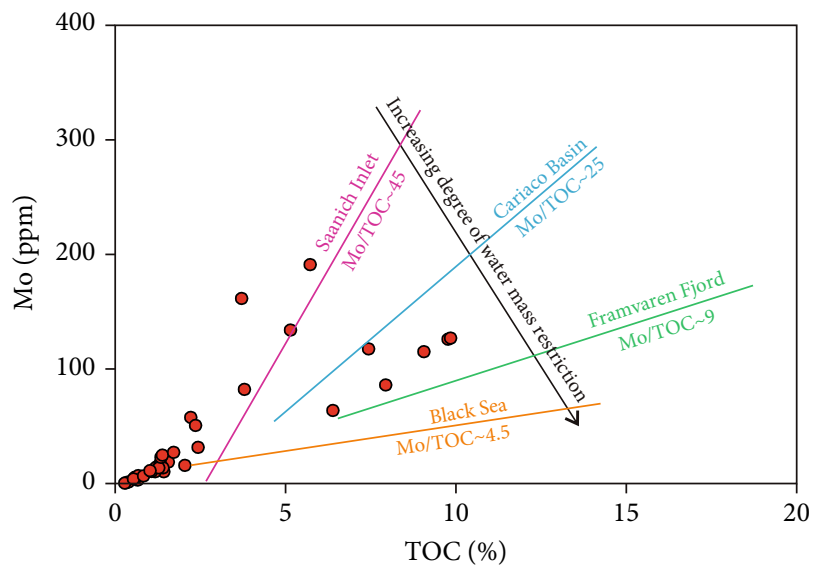

(b)

FIGURE 9: (a) $\mathrm{Mo}_{\mathrm{EF}}-\mathrm{U}_{\mathrm{EF}}$ covariation pattern indicating redox conditions for well Luntan 1. (b) Mo/TOC ratio indicating water mass restriction during the Yuertusi period. The base graphs were cited from [60,61], respectively.

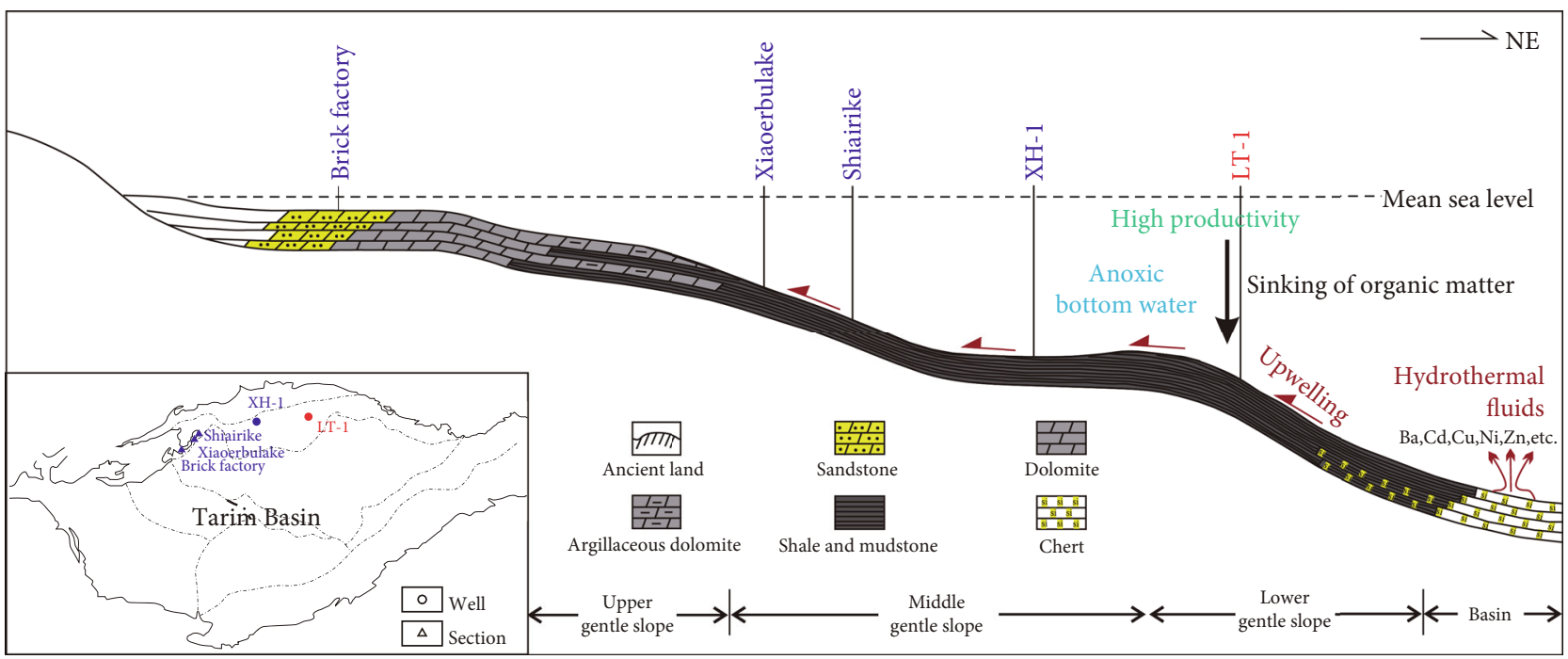

Figure 10: Schematic model of organic matter accumulation of the Lower Cambrian Yuertusi Formation in the Tarim Basin (modified from [19]).

algae [37] contributed high productivity (Figure 5) and supported the materials for the enrichment of organic matter.

The Yuertusi Formation from the western and northeastern margins of the Tarim Basin was mainly deposited in an anoxic environment [27], with some beds in the upper part of the Yuertusi Formation might be deposited in a suboxic condition $[26,63]$. The enrichment of redox-sensitive trace elements (e.g., Mo, U, and V) further indicated anoxiceuxinic environments of the bottom water in well Luntan 1 (Figures 7 and 9(a)). Paleoredox parameters displayed good correlations with TOC content (Figures 7-9(b)), reflecting that the reducing bottom water was favorable to the preservation of organic matter.

High productivity and anoxic condition were developed during the deposition of the Lower Cambrian source rocks across the Tarim Basin, but the sedimentation rates of the organic matter differed from different sedimentary facies. The Yuertusi Formation in well Luntan 1 was deposited in a gentle slope same as that in the northwestern Tarim Basin, such as well Xinghuo 1 (XH-1), the Shiairike, and Xiaoerbulake sections (Figure 10). This gentle slope facies was advantageous to a more moderate sedimentation rate for organic matter accumulation than the deep-water shelf facies belts [27]. Therefore, high-quality source rocks are generally developed in the gentle slope of the Tarim Basin.

\section{Conclusions}

The sedimentary environmental conditions and controlling factors of organic matter enrichment in the Sinian-Lower 
Cambrian strata of well Luntan 1 were evaluated. Based on the analyses of TOC, kerogen carbon isotopes, and major and trace elements, the following conclusions were drawn:

(1) Black shales in the lower part of the Cambrian Yuertusi Formation in well Luntan 1 have a relatively high organic carbon content, accompanied by the extreme enrichment of biologically essential trace elements, such as $\mathrm{Cd}, \mathrm{Co}, \mathrm{Cu}, \mathrm{Ni}$, and $\mathrm{Zn}$

(2) High $\mathrm{Ba}_{\mathrm{xs}}$ values and $\mathrm{P}$ concentrations in the Yuertusi Formation indicated high productivity during the period of this formation deposition. Enrichment factors of redox-sensitive trace elements Mo, $\mathrm{U}$, and $\mathrm{V}$ and $\mathrm{Mo}_{\mathrm{EF}}-\mathrm{U}_{\mathrm{EF}}$ covariation pattern suggested that the Qigebulake, Yuertusi, and Xiaoerbulake Formations were deposited in suboxic-anoxic, anoxic-euxinic, and suboxic-oxic environments, respectively

(3) The TOC contents were positively correlated with the paleoproductivity and paleoredox parameters. This showed that high productivity and reducing conditions were the main factors controlling the organic matter enrichment of the Yuertusi Formation in well Luntan 1

\section{Data Availability}

The research data used to support the findings of this study are included within the supplementary information file.

\section{Conflicts of Interest}

The authors declare that they have no conflicts of interest.

\section{Acknowledgments}

This work is supported by the National Oil and Gas Project of China (2017ZX05008002), the National Natural Science Foundation of China (42072145), and the Strategic Priority Research Program of the Chinese Academy of Sciences (XDA14010103).

\section{Supplementary Materials}

The research data of TOC, $\delta^{13} \mathrm{C}_{\mathrm{ker}}$, and major and trace elements of the samples from well Luntan 1 to support the findings of this study were provided in the supplementary file. (Supplementary Materials)

\section{References}

[1] G. Zhu, T. Wang, Z. Xie, B. Xie, and K. Liu, "Giant gas discovery in the Precambrian deeply buried reservoirs in the Sichuan Basin, China: implications for gas exploration in old cratonic basins," Precambrian Research, vol. 262, pp. 45-66, 2015.

[2] W. Zhao, S. Hu, Z. Wang, S. Zhang, and T. Wang, "Petroleum geological conditions and exploration importance of Proterozoic to Cambrian in China," Petroleum Exploration and Development, vol. 45, no. 1, pp. 1-14, 2018.
[3] Z. L. He, X. H. Jin, Y. J. Wo et al., "Hydrocarbon accumulation characteristics and exploration domains of ultra-deep marine carbonates in China," China Petroleum Exploration, vol. 24, no. 4, pp. 403-417, 2016.

[4] J. Li, Y. Q. She, Y. Gao, G. R. Yang, M. P. Li, and S. Yang, "Onshore deep and ultra-deep natural gas exploration fields and potentials in China," China Petroleum Exploration, vol. 24, no. 4, pp. 403-417, 2019.

[5] G. Y. Zhu and S. C. Zhang, "Hydrocarbon accumulation conditions and exploration potential of deep reservoirs in China," Acta Petrolei Sinica, vol. 30, no. 6, pp. 793-802, 2009.

[6] S. C. Zhang, H. P. Huang, J. Su, and M. Liu, "Ultra-deep liquid hydrocarbon exploration potential in cratonic region of the Tarim Basin inferred from gas condensate genesis," Fuel, vol. 160, pp. 583-595, 2015.

[7] G. Y. Zhu, Y. H. Cao, L. Yan, Y. Haijun, S. Chonghao, and Z. Zhiyao, "Petroleum exploration potential and favorable areas of ultra-deep marine strata deeper than 8000 meters in Tarim Basin," Natural Gas Geoscience, vol. 29, no. 6, pp. 755-772, 2018.

[8] G. Y. Zhu, Z. Y. Zhang, X. X. Zhou, T. T. Li, J. F. Han, and C. H. Sun, "The complexity, secondary geochemical process, genetic mechanism and distribution prediction of deep marine oil and gas in the Tarim Basin, China," Earth-Science Reviews, vol. 198, article 102930, 2019.

[9] Z. Y. Xiao, G. H. Huang, Y. H. Lu, Q. C. Zhang, and Y. Wu, "Origin of oils from Well Tadong 2 in Tarim Basin," Acta Sedimentologica Sinica, vol. 22, Supplement 1, pp. 66-72, 2004.

[10] X. X. Zhai, Y. Gu, Y. X. Qian, C. S. Jia, J. Wang, and J. Lin, "Geochemical characteristics of the Cambrian oil and gas in Well Tashen 1, the Tarim Basin," Petroleum Geology \& Experiment, vol. 29, no. 4, pp. 329-333, 2007.

[11] J. J. Guo, J. F. Chen, T. G. Wang, Z. X. Ye, X. H. Zhou, and S. B. Shi, "New progress in studying Cambrian source rock of Tarim Basin," Acta Sedimentologica Sinica, vol. 26, no. 3, pp. 518$524,2008$.

[12] Z. M. Wang, H. W. Xie, Y. Q. Chen, Y. M. Qi, and K. Zhang, "Discovery and exploration of Cambrian subsalt dolomite original hydrocarbon reservoir at Zhongshen-1 well in Tarim Basin," China Petroleum Exploration, vol. 19, no. 2, pp. 1-13, 2014.

[13] D. F. Song, T. G. Wang, and M. J. Li, "Geochemistry and possible origin of the hydrocarbons from wells Zhongshen 1 and Zhongshen 1C, Tazhong uplift," Science China Earth Science, vol. 46, no. 1, pp. 107-117, 2016.

[14] H. J. Yang, Y. Q. Chen, J. Tian et al., "Great discovery and its significance of ultra-deep oil and gas exploration in well Luntan-1 of the Tarim Basin," China Petroleum Exploration, vol. 25, no. 2, pp. 62-72, 2020.

[15] C. Cai, K. Li, A. Ma et al., "Distinguishing Cambrian from Upper Ordovician source rocks: evidence from sulfur isotopes and biomarkers in the Tarim Basin," Organic Geochemistry, vol. 40, no. 7, pp. 755-768, 2009.

[16] C. Cai, C. Zhang, R. H. Worden et al., "Application of sulfur and carbon isotopes to oil-source rock correlation: a case study from the Tazhong area, Tarim Basin, China," Organic Geochemistry, vol. 83-84, pp. 140-152, 2015.

[17] F. Yang, Y. Lu, T. Wang, Y. Ding, and M. Li, "Geochemical characteristics of the Cambrian source rocks in the Tarim Basin and oil-source correlation with typical marine crude oil,” Oil \& Gas Geology, vol. 38, no. 5, pp. 851-861, 2017. 
[18] A. L. Ma, H. L. Li, J. H. Li et al., "The geochemical characteristics of Middle-Upper Ordovician source rocks in Keping outcrops profiles and marine oil-source correlation," Natural Gas Geoscience, vol. 31, no. 1, pp. 47-60, 2020.

[19] G. Zhu, F. Chen, Z. Chen et al., "Discovery and basic characteristics of high-quality source rocks found in the Yuertusi Formation of the Cambrian in Tarim Basin, China," Journal of Natural Gas Geoscience, vol. 1, no. 1, pp. 21-33, 2016.

[20] Y. Li, Z. Wang, P. Wu et al., "Organic geochemistry of Upper Paleozoic source rocks in the eastern margin of the Ordos Basin, China: input and hydrocarbon generation potential," Journal of Petroleum Science and Engineering, vol. 181, article 106202, 2019.

[21] Y. Li, Z. Wang, Q. Gan, X. Niu, and W. Xu, "Paleoenvironmental conditions and organic matter accumulation in Upper Paleozoic organic-rich rocks in the east margin of the Ordos Basin, China," Fuel, vol. 252, pp. 172-187, 2019.

[22] Q. Li, S. Wu, D. Xia, X. You, H. Zhang, and H. Lu, "Major and trace element geochemistry of the lacustrine organic-rich shales from the Upper Triassic Chang 7 Member in the southwestern Ordos Basin, China: implications for paleoenvironment and organic matter accumulation," Marine and Petroleum Geology, vol. 111, pp. 852-867, 2020.

[23] Y. Liu, B. Wu, Q. Gong, and H. Cao, "Geochemical characteristics of the lower Silurian Longmaxi Formation on the Yangtze platform, South China: implications for depositional environment and accumulation of organic matters," Journal of Asian Earth Sciences, vol. 184, article 104003, 2019.

[24] Y. F. Li, T. W. Zhang, G. S. Ellis, and D. Y. Shao, "Depositional environment and organic matter accumulation of Upper Ordovician- Lower Silurian marine shale in the Upper Yangtze Platform, south China," Palaeogeography, Palaeoclimatology, Palaeoecology, vol. 466, pp. 252-264, 2017.

[25] T. He, S. Lu, W. Li et al., "Paleoweathering, hydrothermal activity and organic matter enrichment during the formation of earliest Cambrian black strata in the northwest Tarim Basin, China," Journal of Petroleum Science and Engineering, vol. 189, article 106987, 2020.

[26] C. Zhang, S. Guan, L. Wu, R. Ren, L. Wang, and X. Wu, "Depositional environments of early Cambrian marine shale, northwestern Tarim Basin, China: implications for organic matter accumulation," Journal of Petroleum Science and Engineering, vol. 194, article 107497, 2020.

[27] Q. Deng, H. Wang, Z. Wei et al., "Different accumulation mechanisms of organic matter in Cambrian sedimentary successions in the western and northeastern margins of the Tarim Basin, NW China," Journal of Asian Earth Sciences, vol. 207, article 104660, 2021.

[28] S. M. Rimmer, "Geochemical paleoredox indicators in Devonian-Mississippian black shales, Central Appalachian Basin (USA)," Chemical Geolology, vol. 206, no. 3-4, pp. 373-391, 2004.

[29] W. Q. Pan, Y. Q. Chen, Y. X. Xiong, B. H. Li, and R. Xiong, "Sedimentary facies research and implications to advantaged exploration regions on lower Cambrian source rocks, Tarim Basin," Nature Gas Geoscience, vol. 26, pp. 1224-1232, 2015.

[30] L. Tian, H. F. Cui, J. Liu, N. C. Zhang, and X. Q. Shi, "Earlymiddle Cambrian paleogeography and depositional evolution of Tarim Basin," Oil \& Gas Geology, vol. 39, no. 5, pp. 10111021, 2018.

[31] Y. J. Li, H. J. Yang, G. Y. Zhang et al., "Redivision of the tectonic units of Tabei Rise in Tarim Basin, NW China," Acta Petrologica Sinica, vol. 28, no. 8, pp. 2466-2478, 2012.
[32] D. B. Ma, W. J. Cui, X. W. Tao et al., "Structural characteristics and evolution process of faults in the Lunnan low uplift, Tabei uplift in the Tarim Basin, NW China," Natural Gas Geoscience, vol. 31, no. 5, pp. 647-657, 2020.

[33] H. J. Yang, F. Hao, J. F. Han, Z. X. Cai, and Q. Y. Gu, "Fault systems and multiple oil-gas accumulation play of the Lunnan lower uplift, Tarim Basin," Chinese Journal of Geology, vol. 42, no. 4, pp. 795-811, 2007.

[34] H. Liu, Z. Liao, H. Zhang, Y. Tian, B. Cheng, and S. Yang, "Stable isotope $\left(\delta^{13} \mathrm{C}_{\mathrm{ker}}, \delta^{13} \mathrm{C}_{\mathrm{carb}}, \delta^{18} \mathrm{O}_{\text {carb }}\right)$ distribution along a Cambrian outcrop section in the eastern Tarim Basin, NW China and its geochemical significance," Geoscience Frontiers, vol. 8, no. 1, pp. 163-170, 2017.

[35] W. H. Liu, G. Hu, J. W. Tenger, L. F. Lu, and X. M. Xie, "Organism assemblages in the Paleozoic source rocks and their implications," Oil \& Gas Geology, vol. 37, pp. 617-626, 2016.

[36] G. Hu, Q. Q. Meng, J. Wang et al., "The original organism assemblages and kerogen carbon isotopic compositions of the early Paleozoic source rocks in the Tarim Basin, China," Acta Geology Sinica (English Edition), vol. 6, pp. 2297-2309, 2018.

[37] Q. L. Chen, X. Yang, C. L. Chu et al., "Recognition of depositional environment of Cambrian source rocks in Tarim Basin," Oil \& Gas Geology, vol. 36, no. 6, pp. 880-887, 2015.

[38] C. H. Van der Weijden, "Pitfalls of normalization of marine geochemical data using a common divisor," Marine Geology, vol. 184, no. 3-4, pp. 167-187, 2002.

[39] F. M. M. Morel, "The co-evolution of phytoplankton and trace element cycles in the oceans," Geobiology, vol. 6, no. 3, pp. 318-324, 2008.

[40] L. J. Robbins, S. V. Lalonde, N. J. Planavsky et al., "Trace elements at the intersection of marine biological and geochemical evolution," Earth-Science Reviews, vol. 163, pp. 323-348, 2016.

[41] N. Tribovillard, T. J. Algeo, T. Lyons, and A. Riboulleau, "Trace metals as paleoredox and paleoproductivity proxies: an update," Chemical Geology, vol. 232, no. 1-2, pp. 12-32, 2006.

[42] S. E. Calvert and T. F. Pedersen, "Elemental proxies for paleoclimatic and palaeoceanographic variability in marine sediments: interpretation and application," Development in Marine Geology, vol. 1, pp. 567-644, 2007.

[43] S. D. Schoepfer, J. Shen, H. Wei, R. V. Tyson, E. Ingall, and T. J. Algeo, "Total organic carbon, organic phosphorus, and biogenic barium fluxes as proxies for paleomarine productivity," Earth-Science Review, vol. 149, pp. 23-52, 2015.

[44] J. Shen, S. D. Schoepfer, Q. Feng et al., "Marine productivity changes during the end-Permian crisis and Early Triassic recovery," Earth-Science Reviews, vol. 149, pp. 136-162, 2015.

[45] D. A. Timothy and S. E. Calvert, "Systematics of variations in excess $\mathrm{Al}$ and $\mathrm{Al} / \mathrm{Ti}$ in sediments from the central equatorial Pacific," Paleoceanography, vol. 13, no. 2, pp. 127-130, 1998.

[46] S. R. Taylor and S. M. McLennan, The Continental Crust: Its Composition and Evolution, Blackwell, Oxford, 1985.

[47] K. Liu, Q. Feng, J. Shen, M. Khan, and N. J. Planavsky, "Increased productivity as a primary driver of marine anoxia in the Lower Cambrian," Palaeogeography, Palaeoclimatology, Palaeoecology, vol. 491, pp. 1-9, 2018.

[48] R. S. Ganeshram, T. F. Pedersen, S. E. Calvert, and R. Francois, "Reduced nitrogen fixation in the glacial ocean inferred from changes in marine nitrogen and phosphorus inventories," Nature, vol. 415, no. 6868, pp. 156-159, 2002. 
[49] A. Paytan and K. Mclaughlin, "The oceanic phosphorus cycle," Chemical Reviews, vol. 107, no. 2, pp. 563-576, 2007.

[50] B. Yu, H. Dong, E. Widom, J. Chen, and C. Lin, "Geochemistry of basal Cambrian black shales and cherts from the northern Tarim Basin, northwest China: implications for depositional setting and tectonic history," Journal of Asian Earth Science, vol. 34, no. 3, pp. 418-436, 2009.

[51] J. Shen, L. Zhou, Q. L. Feng et al., "Paleo-productivity evolution across the Permian-Triassic boundary and quantitative calculation of primary productivity of black rock series from the Dalong Formation, South China," Science China Earth Sciences, vol. 57, no. 7, pp. 1583-1594, 2014.

[52] B. Jones and D. A. C. Manning, "Comparison of geochemical indices used for the interpretation of palaeoredox conditions in ancient mudstones," Chemical Geology, vol. 111, no. 1-4, pp. 111-129, 1994.

[53] H. Kimura and Y. Watanabe, "Oceanic anoxia at the Precambrian-Cambrian boundary," Geology, vol. 29, no. 11, pp. 995-998, 2001.

[54] S. W. Poulton and D. E. Canfield, "Ferruginous conditions: a dominant feature of the ocean through Earth's history," Elements, vol. 7, no. 2, pp. 107-112, 2011.

[55] L. M. Och, G. A. Shields-Zhou, S. W. Poulton et al., "Redox changes in Early Cambrian black shales at Xiaotan section, Yunnan Province, south China," Precambrian Research, vol. 225, pp. 166-189, 2013.

[56] C. Guan, C. Zhou, W. Wang, B. Wan, X. Yuan, and Z. Chen, "Fluctuation of shelf basin redox conditions in the early Ediacaran: evidence from Lantian Formation black shales in south China," Precambrian Research, vol. 245, pp. 1-12, 2014.

[57] C. Jin, C. Li, T. J. Algeo et al., "Highly heterogeneous "poikiloredox" conditions in the early Ediacaran Yangtze Sea," Precambrian Research, vol. 311, pp. 157-166, 2018.

[58] T. J. Algeo and C. Li, "Redox classification and calibration of redox thresholds in sedimentary systems," Geochimica et Cosmochimica Acta, vol. 287, pp. 8-26, 2020.

[59] T. J. Algeo and J. Liu, "A re-assessment of elemental proxies for paleoredox analysis," Chemical Geology, vol. 540, article $119549,2020$.

[60] T. J. Algeo and N. Tribovillard, "Environmental analysis of paleoceanographic systems based on molybdenum-uranium covariation," Chemical Geology, vol. 268, no. 3-4, pp. 211225, 2009.

[61] T. J. Algeo and T. W. Lyons, "Mo-total organic carbon covariation in modern anoxic marine environments: implications for analysis of paleoredox and paleohydrographic conditions," Paleoceanography, vol. 21, article PA1016, 2006.

[62] T. J. Algeo and H. Rowe, "Paleoceanographic applications of trace-metal concentration data," Chemical Geology, vol. 324325, pp. 6-18, 2012.

[63] Z. M. Jin, X. C. Tan, H. Tang et al., "Sedimentary environment and petrological features of organic-rich fine sediments in shallow water overlapping deposits: a case study of Cambrian Yuertus Formation in northwestern Tarim Basin, NW China," Petroleum Exploration and Development, vol. 47, no. 3, pp. 476-489, 2020.

[64] B. M. Zhang, S. C. Zhang, L. Z. Bian, Z. J. Jin, and D. R. Wang, "Initial discussion on the developmental model of Neoproterozoic-Lower Paleozoic marine source rocks in China," Chinese Science Bulletin, vol. 52, no. Z1, pp. 58-69, 2007.
[65] S. Turner, "Sedimentary record of Late Neoproterozoic rifting in the NW Tarim Basin, China," Precambrian Research, vol. 181, no. 1-4, pp. 85-96, 2010.

[66] C. Lin, H. Li, and J. Liu, "Major unconformities, tectonostratigraphic frameword, and evolution of the superimposed Tarim Basin, northwest China," Journal of Earth Science, vol. 23, no. 4, pp. 395-407, 2012.

[67] X. Zhou, D. Chen, H. Qing, Y. Qian, and D. Wang, "Submarine silica-rich hydrothermal activity during the earliest Cambrian in the Tarim Basin, northwest China," International Geology Review, vol. 56, no. 15, pp. 1906-1918, 2014. 